\title{
Microbiota Assay of Cocoa Pod Husk - Based Compost as Organic Fertilizer
}

\author{
M.O. Ogunlade ${ }^{1}$, O.S. Bello ${ }^{2}$, S.O. Agbeniyi ${ }^{1}$ and D.O. Adeniyi ${ }^{1 *}$ \\ ${ }^{1}$ Cocoa Research Institute of Nigeria, PMB 5244, Ibadan, Nigeria \\ ${ }^{2}$ Department of Soil Science, University of Calabar, Calabar, Nigeria \\ *Corresponding author
}

\section{Keywords}

Compost, Cocoa

pod husks,

Microbiota, Colony count, Fertility

Article Info

Accepted:

18 May 2019

Available Online:

10 June 2019

\section{A B S T R A C T}

Microorganisms play important roles in the recycling of agricultural wastes. Composting is the degradation of organic materials through the activities of diverse microorganisms. The compost generated by bioconversion of agro-residues offers several benefits such as enhanced soil fertility and soil health which can lead to increased agricultural productivity, improved soil biodiversity, reduced ecological risks and a healthier environment. This investigation examined the microbial community dynamics, loads and identification of microbiota at various stages of composting process. The compost produced from combinations of fresh and dry cocoa pod husk, Chromolaena odorata and cow-dung were assayed. Composts samples were randomly collected, isolation by standard serial dilution method and identification of microbes from compost materials were carried out at inception, 2, 4, 8 and 12 weeks after set-up of composting. Microorganisms isolated and characterized from the above composts include the species of bacteria viz., Pseudomonas spp., Staphylococcus spp., Streptococcus spp., Escherichia coli, Bacillus spp., Micrococcus spp., Proteus spp., Streptomyces spp, Enterobacter spp., Serratia spp., Salmonella spp. and Shigella dysenteriae and fungi viz., Trichoderma spp., Geotrichum spp. Chrysosporium spp., Aspergillus spp., Yeast spp., Absidia spp., Mucor spp., Rhizopus stolonifer, Penicillium spp., Fusarium spp., Phimbens spp., and Microsporium spp. Of these isolates, Bacillus spp., Staphylococcus spp., E. coli and Streptococcus spp. are common to all stages of composting while Yeast, Mucor and Penicillium were the mycoflora common to all stages of the total microbial isolates. Composts supported high population level of bacteria (Bacillus 86.7\%) while Yeast had 60\% occurrence among fungi isolates. The microbial load of bacteria varied between $7 \times 10^{6} \mathrm{cfu}$ and $12 \times 10^{6} \mathrm{cfu}$ and $2 \times 10^{3} \mathrm{cfu}$ and $5 \times 10^{3} \mathrm{cfu}$ for fungi isolates. The associated isolates were highest (20 isolates) at 2 weeks of composting and the population decrease with maturity of the compost.

\section{Introduction}

Composting is the biological conversion of solid organic waste into usable end products such as fertilizers substrates and biogas.
Moreover, their high organic matter content and biological activity make composts effective in a variety of applications, including erosion control, re-vegetation, biofiltration and bio-remediation (Anastasi, et 
al., 2005). The active component involved in the biodegradation and conversion processes during composting is the resident microbial community, among which fungi and bacteria play very important roles (Anastasi et al., 2005). The biological process of composting comprises of the complete or partial degradation of a variety of chemical compounds by a consortium of microorganisms, the composition of which changes as composting progresses (Whitney and Lynch 1996). The microbial community during composting follows a predictable successional pattern resulting in the recolonization of compost with metabolically active mesophilic populations that can be suppressive towards plant pathogens. Composting is a controlled aerobic process that degrades organic waste to stable material, with the resident microbial community mediating the biodegradation and conversion processes (Neher et al., 2013).

Microorganisms play very significant role in biodegradation of compost materials, bacteria and fungi species play significant roles in the decomposition and mineralization of agricultural organic wastes (Zhang et al., 2014). There are three distinct successional phases driving chemical and microbial changes through time, phases that are determined primarily by changes in temperature (Psychophilic) $<20^{\circ} \mathrm{C}$ : Mesophilic phase (moderate temperatures rising to $45^{\circ} \mathrm{C}$ ), Thermophilic phase (high temperatures peaking $70^{\circ} \mathrm{C}$ ), curing phase (cooling to ambient temperature) (Ryckeboer et al., 2003). Compost production is a critical component of organic waste handling, and compost applications to soil are increasingly important to crop production. The primary goals of composting have included the save handling of organic wastes and enhancement of soil's fertility (Hubbe et al., 2010).

Various biological studies have been carried out to identify the major microbiological agents responsible for biodegradation (Taiwo and Oso, 2004). Macdonald et al., (1981) noted that the composting process was brought about by several organisms such as bacteria, fungi, actinomycetes and protozoa and may also involve invertebrates such as nematodes, pot worms, earthworms, mites and various other organisms. Singh (1987) however noted that the sole agents of decomposition of carbonaceous materials are the heterotrophic microorganisms some of which were cultured in this study.

Generally, successful composting depends on a number of factors that have both direct and indirect influence on the activities of the microorganisms. They include the type of raw materials being composted, its nutrient composition, moisture content, temperature, acidity or alkalinity and aeration. Composting is a fertilizing mixture of partially decomposed organic matter from plant and animal origin (Piet et al., 1990). The active component mediating the biodegradation and conversion processes during composting is the resident microbial community, among which fungi play a very important role. Therefore, optimization of compost quality is directly linked to the composition and succession of microbial communities in the composting process (Taiwo and Oso, 2004, Peters et al., 2000).

Cocoa pod husk $(\mathrm{CPH})$, fresh and dry is generated in large quantities in cocoa farms in Nigeria.Nigeria produces annually about $8,000,000$ tonnes of Cocoa Pod Husk (CPH), which are left to waste. By this it was estimated that 64000-94000 tonnes of nutrients like $\mathrm{K}, \mathrm{Ca}$ and $\mathrm{P}$ and between 60009000 tonnes of $\mathrm{N}$ are lost annually (Egunjobi, 1975, Ajayi et al., 2007). Cocoa pod husk and its ash have not been adequately studied in plant nutrition. Ayeni et al., (2008a) reported cocoa pod ash contained plant nutrients as $\mathrm{N}$, $\mathrm{P}, \mathrm{K} \mathrm{Ca}, \mathrm{Mg}$ and micronutrients and is good for tomato production (Odedina et al., 2003, 
Ayeni, 2010). These CPH either fresh or dry could be composted for use as organic fertilizer for cocoa or any other crop. The major difference between the fresh and dry cocoa pod husk is the water content.

Composts were made from fresh $\mathrm{CPH}$, dry $\mathrm{CPH}$ and combination of both, while bacteria and fungi associated with composts of different sources were cultured. This study also carried out co-composting of (i) fresh CPH with Chromolaena odorata and cow dung (ii) dry $\mathrm{CPH}$ with Chromolaena odorata and cow dung (iii) dry $\mathrm{CPH}$, fresh $\mathrm{CPH}$ with Chromolaena odorata and cow dung with a view to determine the microbiota status of each compost-type during composting and determine the nutrient contents and quality of the final compost.

\section{Materials and Methods}

Various composts were prepared using fresh, dry cocoa pod husk and combination of both as substrates. This research is a farmers' participatory approach study carried out in Cross River State, Nigeria. Cocoa plantation at Effraya, Etung LGA, Cross River State was randomly selected. Participating farmers were involved in the choice of compost materials. Fresh and dry cocoa pods generated on cocoa plantation, Chromolaena odorata leaves were also harvested on adjacent plots and cow dung was sourced from the nearby Abattoir at Ikom, close to the experimental site. Necessary chopping and shredding was done as per requirement as it helps speed up decomposition and hasten the process of composting by increasing the surface area available for microbial action, and providing better aeration (Taiwo and Oso, 2004; Nielsen et al., 1997; Strom, 1985). The cocoa pod husks was weighed with Chromolaena odorata and cow dung in ratio 2:0.5:0.5 respectively and thoroughly mixed before packing into composting boxes. The experiment comprises of three compost combinations which were as follows: Fresh
$\mathrm{CPH}+$ Chromolaena odorata + cowdung (2:0.5:0.5); Dry CPH + Chromolaena odorata + cowdung (2:0.5:0.5); Fresh CPH + Dry $\mathrm{CPH}+$ Chromolaena odorata + cowdung (1:1:0.5:0.5).

All the test composts were run in triplicate. The single and combination of substrates were prepared and monitored for composting outside for the period of 12 weeks at the end of cooling phase. Water was added until moisture content was adjusted between 4060\% (Buswell, 1984). Proper turning was done to get homogenous compost. As the composting progressed, the materials were regularly inspected using the traditional technique of touch and smell method. Moisture retention capacity of the compost was maintained and the temperature was noted successively till maturity.

Compost materials were randomly collected from the boxes, isolation of microorganisms was carried out at difference stages of composting viz., inception, 2, 4, 8 and 12 weeks after set-up and standard plate count (SPC) was performed according to Pelczar et al., (2003). Ten-fold serial dilutions were made up to $10^{-3}$ and $10^{-6}$. An amount of $1.0 \mathrm{ml}$ from the diluted samples were spread on Nutrient Agar (for bacteria) and Potato Dextrose Agar (for fungi) using a glass spreader. Petri plates were then incubated at ambient temperature for $24 \mathrm{~h}$ for bacteria and 4-5 days for fungi. The isolates were maintained on respective media slants. Prevalence of different groups of microorganisms was calculated in terms of appearance. These isolates were identified on the basis of conventional cultural and morphological characteristics of Barnett and Hunter, (1998); Barnett, 1960; and Brown (2005).

\section{Results and Discussion}

The research study shows a comprehensive 
composition of microorganism in composts based on fresh and dry CPH substrates. The substrates utilized for composting are critical in composting and have impact on the type of active microbiota in the process. A total of 24 genera of microorganisms were isolated from composts at various stages of the process.

The bacteria isolates were Pseudomonas spp., Staphylococcus spp., Streptococcus spp., Escherichia coli, Bacillus spp., Micrococcus spp., Proteus spp., Streptomyces spp, Enterobacter spp., Serratia spp., Salmonella spp. and Shigella dysenteriae and the fungi include Trichoderma spp., Geotrichum spp. Chrysosporium spp., Aspergillus spp., Yeast spp., Absidia spp., Mucor spp., Rhizopus stolonifer, Penicillium spp., Fusarium spp., Phimbens spp., and Microsporium spp. The large majority $(86.7 \%)$ occurrence was the genus Bacillus, followed by $73.3 \%$ occurrence of Staphylococcus while genus Yeast comprises of $60 \%$ of the total microbial isolates (Table 1). Substrates used in the study were composted singly and in combinations. It was observed that in comparison with the composts prepared from fresh single composts, combination of fresh $\mathrm{CPH}$ and dry $\mathrm{CPH}$ enhanced the diversity of saprophytic microorganisms that play an important role in the biodegradation process.

The microbial population of the composts varied with stages of composting, the isolate population was least by the $12^{\text {th }}$ week (termination of the process) and highest of 20 genera of microbial isolates were recorded by at the $2^{\text {nd }}$ week of composting activity. Bacillus, Staphylococcus, E. coli, and Streptococcus were the most prominent fungi across the sampling stages of composting; Shigella dysenteriae and Chrysosporium sp. were the least isolates present of the total microbial population (Table 1).

The study explains that when a microorganism is incubated in the presence of two or more materials, the materials will be degraded in the order of their ease of degradation.

Besides that, presence of two materials also increased the variety of microorganisms and that proper composting promotes the development of a number of saprophytic soil microorganisms.

Species of Bacillus, Enterobacter, Flavobacterium, Pseudomonas, Streptomyces, Nocardia, Penicillium, Trichoderma and Micrococus have been reported by Anastasi et al., (2005); Taiwo and Oso (2004) and Ryckeboer et al., (2003) and that the cellulytic fungi such as Geotrichum, Mucor, Microsporium, Fusarium, Rhizopus, Aspergillus, Trichoderma, Penicillium and Trichurus accelerate composting for efficient recycling of crop wastes with high $\mathrm{C}: \mathrm{N}$ ratio.

Large and diversified microbial populations were found to be present during the composting process as well as in mature compost, and the appearance of some microorganisms stated above reflects the quality of maturing compost for good nutrients of plant use.

The Prevalence of the listed groups of microorganisms in composts based on multiple substrates is good indication of high quality compost.

Variations were recorded in the presence of microbial isolates at the sampling stages of composting with higher percent (57\%) of bacteria recorded at composting initiation, $55 \%$ at 2 weeks of composting and $56 \%$ at 12 weeks. The fungi population was $56 \%$ and $60 \%$ at 4 and 8 weeks of composting activity respectively (Figure 1). 
Table.1 Frequency of occurrence of microbial isolates in different stages of composting

\begin{tabular}{|c|c|c|c|c|c|c|c|c|c|c|c|c|c|c|c|c|}
\hline \multirow{3}{*}{ Microbial isolates } & \multicolumn{15}{|c|}{ Occurrence of microbial isolates in composting stages } & \multirow{3}{*}{$\begin{array}{l}\text { Percent } \\
\text { occurre } \\
\text { nce }(\%)\end{array}$} \\
\hline & \multicolumn{3}{|c|}{ Inception } & \multicolumn{3}{|c|}{2 weeks } & \multicolumn{3}{|c|}{4 weeks } & \multicolumn{3}{|c|}{8 weeks } & \multicolumn{3}{|c|}{12 weeks } & \\
\hline & FPH & DPH & FDPH & FPH & DPH & FDPH & FPH & $\mathrm{DPH}$ & FDPH & FPH & DPH & FDPH & FPH & DPH & FDPH & \\
\hline \multicolumn{16}{|c|}{ Bacterial isolate on occurrences } & \\
\hline Bacillus sp. & + & + & + & + & - & + & + & + & + & + & + & + & + & + & - & 86.7 \\
\hline Staphylococcus sp. & - & + & - & + & + & + & + & + & + & + & + & + & + & - & - & 73.3 \\
\hline Proteus sp. & - & + & - & - & + & - & + & + & + & - & - & - & - & - & - & 33.3 \\
\hline Streptococcus sp. & - & - & + & + & - & - & - & - & - & + & + & + & - & + & - & 40.0 \\
\hline Micrococcus sp. & - & + & - & + & - & - & - & + & - & + & - & - & + & + & - & 40.0 \\
\hline Serratia sp. & - & - & - & - & - & + & - & + & - & - & - & - & - & - & - & 13.3 \\
\hline Escherichia coli & + & - & - & + & + & + & - & - & + & - & + & + & - & + & - & 53.3 \\
\hline Salmonella sp. & - & - & + & + & - & - & - & - & - & - & - & - & - & - & - & 13.3 \\
\hline Enterobacter sp. & + & - & - & + & - & + & - & - & - & - & - & + & - & - & - & 26.7 \\
\hline Shigella dysenteriae & - & - & - & - & - & - & + & - & - & - & - & - & - & - & - & 6.7 \\
\hline Streptomyces sp. & - & - & - & - & + & + & - & - & - & - & - & - & - & - & - & 13.3 \\
\hline Pseudomonas sp. & - & - & - & - & + & - & - & + & - & - & - & - & - & - & - & 13.3 \\
\hline \multicolumn{16}{|c|}{ Fungal isolate occurrences } & \\
\hline Trichoderma sp. & - & - & - & - & + & - & + & + & + & - & - & - & - & - & - & 26.7 \\
\hline Geotrichum sp. & - & - & - & + & - & - & - & + & + & + & - & - & - & - & + & 33.3 \\
\hline Chrysosporium sp & - & - & - & + & - & - & - & - & - & - & - & - & - & - & - & 6.7 \\
\hline Aspergillus sp. & + & + & + & + & - & - & - & + & + & + & - & + & - & - & - & 53.3 \\
\hline Yeast sp. & + & - & + & + & - & + & + & - & + & + & + & - & + & - & - & 60.0 \\
\hline Absidia sp. & - & - & - & - & - & - & + & - & + & - & - & - & - & - & - & 13.3 \\
\hline Mucor sp. & + & - & - & - & - & + & - & + & + & - & + & + & - & + & - & 46.7 \\
\hline Rhizopus sp. & - & + & - & - & - & - & - & + & - & - & + & - & - & - & - & 20.0 \\
\hline Penicillium sp. & - & - & + & - & - & + & - & + & - & - & + & - & + & - & - & 33.3 \\
\hline Fusarium sp. & - & - & - & - & - & - & - & - & + & - & + & - & - & - & - & 13.3 \\
\hline Phimbens sp. & - & - & - & - & - & + & - & - & - & - & + & + & - & - & - & 20.0 \\
\hline Microsporium sp. & - & - & - & - & + & - & + & + & - & + & - & + & - & - & - & 33.3 \\
\hline Number of isolates & \multicolumn{3}{|c|}{14} & \multicolumn{3}{|c|}{20} & \multicolumn{6}{|c|}{15} & \multicolumn{3}{|c|}{9} & \\
\hline
\end{tabular}

*FPH: Fresh Pod Husk; DPH: Dry Pod Husk; FDPH: Fresh and Dry Pod Husk. Present (+); Absent (-). 
Table.2 Inoculum load and identity of microbiota at the inception of composting

\begin{tabular}{|l|l|l|l|l|}
\hline Compost material & \multicolumn{5}{|c|}{ Microbiota associated with compost } \\
\hline & $\begin{array}{l}\text { Colony } \\
\text { count }(* \mathrm{cfu})\end{array}$ & Bacterial isolates & $\begin{array}{l}\text { Colony } \\
\text { count }(\mathrm{cfu})\end{array}$ & Fungal isolates \\
\hline Fresh CPH & $114.0 \times 10^{6}$ & $\begin{array}{l}\text { Enterobacter sp, Bacillus sp, } \\
\text { Escherichia coli }\end{array}$ & $60.0 \times 10^{3}$ & $\begin{array}{l}\text { Mucor spp, Aspergillus spp, } \\
\text { Yeast spp }\end{array}$ \\
\hline Dry CPH & $93.0 \times 10^{6}$ & $\begin{array}{l}\text { Proteus sp, Staphylococcus sp, } \\
\text { Bacillus sp, Micrococcus sp }\end{array}$ & $\begin{array}{l}\text { Aspergillus sp, Rhizopus sp, } \\
\text { Fusarium sp }\end{array}$ \\
\hline $\begin{array}{l}\text { Fresh }+ \\
\mathrm{CPH} \text { Dry }\end{array}$ & $68.0 \times 10^{3}$ & $\begin{array}{l}\text { Streptococcus sp, Salmonella } \\
\text { sp, Bacillus } s p\end{array}$ & $26.0 \times 10^{3}$ & $\begin{array}{l}\text { Yeast spp, Penicillium sp, } \\
\text { Aspergillus sp, Fusarium sp }\end{array}$ \\
\hline
\end{tabular}

Table.3 Inoculum load and identity of microbiota at 2 weeks after set -up of compost

\begin{tabular}{|c|c|c|c|c|}
\hline \multirow{2}{*}{ Compost material } & \multicolumn{4}{|c|}{ Microbiota associated with compost } \\
\hline & $\begin{array}{l}\text { Colony count } \\
(* \mathrm{cfu})\end{array}$ & Bacterial isolates & $\begin{array}{l}\text { Colony } \\
\text { count (cfu) }\end{array}$ & Fungal isolates \\
\hline Fresh CPH & $128.0 \times 10^{6}$ & $\begin{array}{l}\text { Pseudomonas sp, Staphylococcus } \\
\text { sp, Streptococcus sp, Escherichia } \\
\text { coli, Bacillus sp, Micrococcus, } \\
\text { Enterobacter sp, Salmonella }\end{array}$ & $68.0 \times 10^{3}$ & $\begin{array}{l}\text { Aspergillus sp, } \\
\text { Geotrichum sp, } \\
\text { Chrysosporium sp, } \\
\text { Yeast sp }\end{array}$ \\
\hline Dry $\mathrm{CPH}$ & $65.0 \times 10^{6}$ & $\begin{array}{l}\text { Proteus sp, Escherichia coli, } \\
\text { Staphylococcus sp, Streptomyces sp }\end{array}$ & $37.0 \times 10^{3}$ & $\begin{array}{l}\text { Trichoderma sp, } \\
\text { Microsporium } s p\end{array}$ \\
\hline Fresh + Dry CPH & $130.0 \times 10^{6}$ & $\begin{array}{l}\text { Staphylococcus sp, Enterobacter sp, } \\
\text { Bacillus sp, Escherichia coli, } \\
\text { Streptomyces, Serratia sp }\end{array}$ & $75.0 \times 10^{3}$ & $\begin{array}{l}\text { Yeast sp, Mucor } \\
\text { Phimbens, Penicillium } \\
\text { sp }\end{array}$ \\
\hline
\end{tabular}

*Colony forming unit

Table.4 Inoculum load and identity of microbiota at 4 weeks after set-up of compost

\begin{tabular}{|c|c|c|c|c|}
\hline \multirow[t]{2}{*}{ Compost material } & \multicolumn{4}{|c|}{ Microbiota associated with compost } \\
\hline & $\begin{array}{l}\text { Colony } \\
\text { count }(* \mathrm{cfu})\end{array}$ & Bacterial isolates & $\begin{array}{l}\text { Colony } \\
\text { count (cfu) }\end{array}$ & Fungal isolates \\
\hline Fresh $\mathrm{CPH}$ & $66.0 \times 10^{6}$ & $\begin{array}{l}\text { Pseudomonas sp, Shigella } \\
\text { dysenteriae, Staphylococcus } \\
\text { sp, Bacillus sp, Proteus sp }\end{array}$ & $42.0 \times 10^{3}$ & $\begin{array}{l}\text { Trichoderma sp, Absidia sp, Yeast } \\
\text { sp, Microsporium sp }\end{array}$ \\
\hline Dry CPH & $47.0 \times 10^{6}$ & $\begin{array}{l}\text { Proteus sp, Bacillus sp, } \\
\text { Staphylococcus sp, Serratia } \\
\text { sp, Micrococcus sp }\end{array}$ & $43.0 \times 10^{3}$ & $\begin{array}{l}\text { Rhizopus sp, Geotrichum sp, } \\
\text { Penicillium sp, Mucor sp, } \\
\text { Trichoderma sp, Microsporium sp, } \\
\text { Aspergillus sp }\end{array}$ \\
\hline $\begin{array}{l}\text { Fresh }+ \text { Dry } \\
\text { CPH }\end{array}$ & $147.0 \times 10^{6}$ & $\begin{array}{lr}\text { Staphylococcus } & s p, \\
\text { Escherichia coli, } & \text { Proteus } \\
\text { sp, Bacillus sp } & \end{array}$ & $118.0 \times 10^{3}$ & $\begin{array}{l}\text { Trichoderma sp, Geotrichum sp, } \\
\text { Fusarium sp, Absidia sp, Yeast sp, } \\
\text { Aspergillus sp, Mucor sp }\end{array}$ \\
\hline
\end{tabular}

*Colony forming unit 
Table.5 Inoculum load and identity of microbiota at 8 weeks after set -up of compost

\begin{tabular}{|c|c|c|c|c|}
\hline \multirow[t]{2}{*}{ Compost material } & \multicolumn{4}{|c|}{ Microbiota associated with compost } \\
\hline & $\begin{array}{l}\text { Colony } \\
\text { count }(* \mathrm{cfu})\end{array}$ & Bacterial isolates & $\begin{array}{l}\text { Colony count } \\
(\mathrm{cfu})\end{array}$ & Fungal isolates \\
\hline Fresh CPH & $\begin{array}{l}44.0 \times 10^{6} \\
\text { cfu }\end{array}$ & $\begin{array}{l}\text { Streptomyces } \mathrm{sp} \text {, } \\
\text { Staphylococcus sp, Bacillus } \\
\text { sp, Micrococcus sp }\end{array}$ & $13.0 \times 10^{3} \mathrm{cfu}$ & $\begin{array}{l}\text { Aspergillus } s p, \\
\text { Geotrichum sp, } \\
\text { Microsporium sp, Yeast sp }\end{array}$ \\
\hline Dry $\mathrm{CPH}$ & $\begin{array}{l}\begin{array}{l}42.0 \times 10^{6} \\
\text { cfu }\end{array} \\
\end{array}$ & $\begin{array}{l}\text { Escherichia coli, Bacillus } \\
\mathrm{sp}, \quad \text { Staphylococcus sp, } \\
\text { Streptococcus } \mathrm{sp}\end{array}$ & $22.0 \times 10^{6} \mathrm{cfu}$ & $\begin{array}{l}\text { Rhizopus sp, Yeast sp, } \\
\text { Fusarium sp, Mucor } \\
\text { Plumbens, Penicillium sp }\end{array}$ \\
\hline $\begin{array}{l}\text { Fresh } \\
\text { CPH }\end{array}$ & $\begin{array}{l}41.0 \times 10^{6} \\
\text { cfu }\end{array}$ & $\begin{array}{lr}\text { Enterobacter sp, } & \text { Bacillus } \\
\text { sp, Escherichia } & \text { coli, } \\
\text { Staphylococcus } & \mathrm{sp} \text {, } \\
\text { Streptomyces } \mathrm{sp} & \end{array}$ & $16.0 \times 10^{3} \mathrm{cfu}$ & $\begin{array}{l}\text { Mucor plumbens, Yeast } \\
\text { cells, Geotrichum sp, } \\
\text { Aspergillus sp, } \\
\text { Microsporium sp }\end{array}$ \\
\hline
\end{tabular}

*Colony forming unit

Table.6 Inoculum load and identity of microbiota at 12 weeks after set -up of compost

\begin{tabular}{|c|c|c|c|c|}
\hline \multirow[t]{2}{*}{ Compost material } & \multicolumn{4}{|c|}{ Microbiota associated with compost } \\
\hline & $\begin{array}{l}\text { Colony } \\
\text { count }(* \mathrm{cfu})\end{array}$ & Bacterial isolates & $\begin{array}{l}\text { Colony count } \\
(\mathrm{cfu})\end{array}$ & Fungal isolates \\
\hline Fresh CPH & $\begin{array}{l}12.0 \times 10^{6} \\
\text { cfu }\end{array}$ & $\begin{array}{l}\text { Staphylococcus } \\
\text { micrococcus sp, Bacillus sp }\end{array}$ & $5.0 \times 10^{3} \mathrm{cfu}$ & Yeast sp, Penicillium sp \\
\hline Dry CPH & $9.0 \times 10^{6} \mathrm{cfu}$ & Bacillus sp, Streptomyces sp & $5.0 \times 10^{3} \mathrm{cfu}$ & Mucor sp \\
\hline $\begin{array}{l}\text { Fresh }+ \text { Dry } \\
\mathrm{CPH}\end{array}$ & $7.0 \times 10^{6} \mathrm{cfu}$ & $\begin{array}{l}\text { Escherichia coli, } \\
\text { Micrococcus sp }\end{array}$ & $2.0 \times 10^{3} \mathrm{cfu}$ & Geotrichum sp \\
\hline
\end{tabular}

Fig.1 Population load of microbiota associated with compost

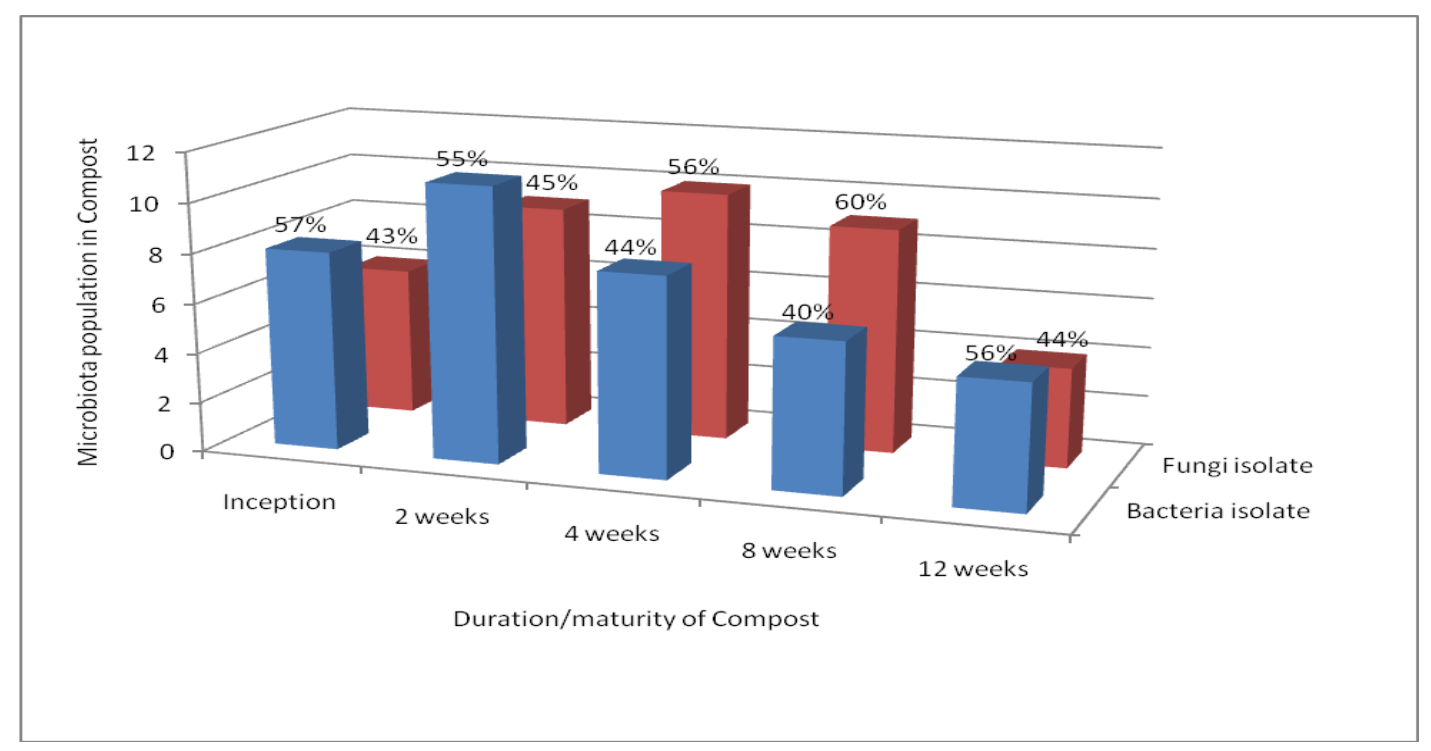


The microbial load of compost substrates varied at different stages of composting and the population of the isolates also differ based on the substrates and duration of compost.

The report of Nakasaki and Ohtaki (2002) indicates that the substrates will be degraded in the order of their ease of degradation when a microorganism is incubated in the presence of two or more substrates. The presence of two substrates also increased the variety of microbes and the higher percentage occurrence of fungi isolates in this study is corroborated by the earlier findings of Rabia et al., (2007) that fungal species were found to be numerous during both mesophilic and thermophilic phases of composting and that the appearance of some microorganisms reflects the quality of maturing compost (Strom, 1985).

The population of both bacteria and fungi were highest in the fresh $\mathrm{CPH}$ based compost at the inception of composting. Fresh and dry $\mathrm{CPH}$ based compost had the least population of bacteria and fungi. These were the initial inoculums that initiated the decomposition of the materials and they were mostly heterotrophic bacteria. Bacillus spp. of bacteria and Aspergillus spp. of fungi occurred in all the compost types at this stage. At inception of composting, bacteria load of $114 \times 10^{6} \mathrm{cfu} / \mathrm{ml}$ was recorded in fresh $\mathrm{CPH}$ while fungi colony was $60 \times 10^{3} \mathrm{cfu} / \mathrm{ml}$ in the same substrate. Bacillus spp. and Aspergillus spp. were recorded in all substrate type, but presence of Streptococcus, Salmonella, Penicillium and Fusarium were recorded in combination of substrates (Table 2). Similar observations were recorded on Seritia sp., Plumbens and Penicillium spp. (Table 3), E. coli and Fusarium spp. (Table 4), Enterobacter (Table 5), E. coli and Geotrichum spp. (Table 6). At two weeks after set-up of compost, the population of bacteria and fungi in the fresh and dry $\mathrm{CPH}$ based compost were highest. The bacterial and fungal isolates at the inception of composting also occurred two weeks after setup, however Serratia spp and Pseudomonas spp were bacteria that surfaced in 2 weeks after while fungi like Trichoderma spp, Geotrichum spp and Chrysosporium spp were isolated newly at 2 weeks after set-up (Table $3)$.

Biodiversity of microbial populations were recorded at different stages of composting process and also in the mature compost. It has been suggested that the appearance of some microorganisms reflects the quality of maturing compost (Strom, 1985).

Shigella dysenteriae was isolated newly and only at 4 weeks after set up of compost in fresh CPH based compost. Pseudomonas spp of bacteria occurred only in fresh $\mathrm{CPH}$ based compost at 2 and 4 weeks after compost setup. Population of bacteria and fungi in the fresh and dry $\mathrm{CPH}$ based compost were highest at 4 weeks after the setting up of the compost (Table 4).

At 8 weeks after compost set-up, no new bacterial isolate was found in all the compost types (Table 6). The populations of bacteria at 8 and 12 weeks after compost set-up were highest in fresh $\mathrm{CPH}$ based compost compared to other types of compost (Tables $5 \& 6)$.

The populations of bacteria and fungi at 8 and 12 weeks were lower than what obtained at 2 and 4 weeks after compost set-up. This might be due to the fact that at 2 and 4 weeks, decomposition of the composting materials was at the peak and require more bacteria and fungi at this stage for decomposition than at 12 weeks when the compost was getting matured. Association of Aspergillus, 
Trichoderma, Mucor, Penicillium, Alternaria, Cladosporium, Monilia, Helminthosporium, Coccidioides, Scedosporium with different composts were reported by Rabia et al., (2007). Jeanine et al., (2002) and Gbolagade (2006) also reported a wide range of bacteria viz., Pseudomonas, Bacillus spp., Serratia, E. coil, Micrococcus roseus, Citrobacter freundii, Clostridium perfringens, Klebsiella, Salmonella spp. and Enterobacter were been associated with compost, and most of these isolates were also identified in this study.

Gbolagade, (2006); Anastasi et al., (2005); Charest et al., (2004); Taiwo and Oso (2004) among others have reported the association of species of Bacillus, Enterobacter, Flavobalistinum, Pseudomonas, Streptomyces, Nocardia, Rhodococcus, Penicillium, Trichoderma and Gliocladium composting process. This corroborates the findings in this study as most of these microbial isolates were equally cultured and identified in this investigation.

In conclusion, the populations of bacteria and fungi at 8 and 12 weeks were lower than what obtained at 2 and 4 weeks after compost setup. This might be due to the fact that at 2 and 4 weeks, decomposition of the composting materials was at the peak and require more bacteria and fungi at this stage for decomposition than at 12 weeks when the compost was getting matured. The combination of fresh and dry cocoa pod husks enhanced not only the number but also the diversity of saprophytic microorganisms that play important role in the biodegradation of the materials at 2 and 4 weeks after compost set-up. Conventional techniques were used to identify the fungal cultures however molecular techniques can be adopted to have a better understanding of active compost fungi. Along with the systematic characterization of fungal communities in compost, a functional analysis is needed to highlight potentials and applications as large unexploited diversity of microorganisms awaits discovery.

\section{References}

Ajayi, C. A., Awodun, M. A. and S.O. Ojeniyi, S. O. (2007). Comparative Effect of Cocoa Pod Husk Ash and NPK Fertilizer on Soil and Root Nutrient Content and Growth of Kola Seedling. International Journal of Soil Science, 2: 148-153.

Anastasi, A., Varese, G. C. and Marchisio, V. F. (2005). Isolation and identification of fungal communities incompost and vermicompost.

Ayeni L.S, Adetunji, M.T and Ojeniyi, S.O (2008a). Comparative nutrient release from cocoa pod ash, poultry manure, NPK 20:10:10 and their combinations Incubation study. Nigerian Soil Science Journal; 18: $23-26$.

Ayeni, L.S. (2010). Effect of Combined Cocoa Pod, Ash and NPK Fertilizer on Soil Properties, Nutrient Uptake and Yield of Maize (Zea mays). Journal of American Science; 6(3); 79.

Brown, A.E. (2005). Benson's microbiological Applications: Laboratory Manual in General Microbiology. (Reidy, P. E., J. S. Fornango, Eds.) McGraw-Hill, Inc., New York, USA.

Buswell, J. A. (1984). Potentials of spent mushroom substrates for bioremediation purposes. Compost 2: 31-35.

Barnett, H. L. and Hunter, B. B. (1980). Illustrated Genera of Imperfect Fungi ( $3^{\text {rd }}$ Edition.)

Barnett, H.L. 1960. Illustrated genera of imperfect fungi. 2nd ed. Burgess Publishing Company.

Barnett, H.L. and B. Hunter. 1998. Illustrated genera of imperfect fungi. 4th ed. APS Press. Minnesota. 
Charest, M.H., H. Antoun and C.J. Beuchamp. 2004. Dynamics of watersoluble carbon substances and microbial populations during the composting of de-inking paper sludge. Bioresource Technology, 91(1): 53-67.

Egunjobi, O.A. (1975). On the possible utilization of discarded cocoa pod husk as fertilizer and nematicide. Proceedings of the 5th International Cocoa Research Conference, September 1-9, Ibadan, pp: 541-547.

Gbolagade, J.S. 2006. Bacteria associated with compost used for cultivation of Nigerian edible mushrooms Pleurotus tuber-regium (Fr.) Singer, and Lentinus squarrosulus (Berk.). African Journal of Biotechnology, 5(4): 338-342.

Hubbe, M. A., Nazhad, M. and Sanchez, C. (2010). Composting as a way to Convert Cellulosic Biomass and Organic Waste into High-Value Soil Amendments; A Review. BioResources 5(4),pp. 2808-2854.

Jeanine, I. B., Greg, J. B. and Jack, T. T. (2002). Assessment of compost for suppression of Fusarium Patch (Microdochium nivale) and Typhula Blight (Typhula ishikariensis) snow molds of turfgrass. Biological Control 25 (2002) 162-172

Macdonald Dow MGC, Griffin Shay E (1981). Returning wastes to the land. In: food, fuel and fertilizer from organic wastes. Report of ad hoc panel of the advisory committee on technology for international development commission on international relations. National Research council. National Academy Press, Washington, DC.

Neher, D. A., Weicht, T. R., Bates, S. T., Leff, J. W. and Fierer, N. (2013). Changes in Bacterial and Fungal Communities across Compost Recipes, Preparation Methods, and Composting Times. PloS ONE 8(11): e79512.

doi:10.1371/journal.pone.0079512.

DOI: $10.1371 /$ journal.pone.0079512

Nakasaki, K. and A. Ohtaki. 2002. A simple numerical model for predicting organic matter decomposition in a fed-batch composting operation. Journal of Environmental Quality. 31: 997-1003.

Nielsen, S. S.; Ohler, T. A.; Mitchell, C.A., 1997. Cowpea leaves for human consumption: production, utilization and nutrient composition. In: Advances in Cowpea Research, B.B. Singh, D.R. Mohan Raj, K.E. Dashiell, L.E.N. Jackai, Editors. I.I.T.A., Ibadan, Nigeria.

Odedina, S.A., Odedina, J. N., Ayeni, S. O., Arowojolu, S. A., S.D. Adeyeye, S. D. and Ojeniyi, S. O. (2003). Effect of types of ash on soil fertility nutrient availability and yield of tomato and pepper. Nig. J. Soil. Sci., 13: 61-67.

Peters, S., Koschinsky, S., Schwieger, F., and Tebbe, C. C. (2000). Succession of microbial communities during hot composting as detected by PCR-singlestrand-conformation polymorphismbased genetic profiles of small-subunit rRNA genes. Appl. Environ. Microbiol., 66(03): 930-936.

Piet, J.L., X. Derik, X., Huub, J. M., Drift, C. V., Leo, J. L. D. and Vogel, D. (1990). Biomass and biological activity during the production of compost used as a substrate in mushroom cultivation. Appl.Environ. Microbiol. 56 (10): 30293034.

Pelczar, M.J.JR, E.C.S. Chan and N.R. Krieg. 2003. Microbiology 5th ed. Tata McGraw Hill Publishing Company Limited New Dehli.

Ryckeboer, J., J. Margaert, J. Coosemans, K. Deprins and J. Swings. (2003). Microbiological aspects of biowaste during composting in a monitored compost bin. Journal of Applied 
Microbiology, 94: 127-137.

Rabia, A., Faiza, S. and Tasneem, A. A. (2007). Association of fungi, bacteria and actinomycetes

With different composts. Pak. J. Bot., 39(6): 2141-2151, 2007.

Singh C.P. (1987). Preparation of High grade Compost by an enrichment on organic matter decomposition. Biol. Agric. Hort. 5: 41-49.

Strom, P.E. 1985. Identification of thermophillic bacteria in solidwaste composting. Appl. Environ. Microbiol., 50(4): 906-913.

Taiwo, L. B. and Oso, B. A. (2004); Influence of Composting techniques on microbial successions, temperature and $\mathrm{pH}$ in a composting municipal solid waste.
African Journal of Biotechnology Vol. 3(4), pp. 239-243.

Whitney, P.J. and Lynch, J.M. 1996 Importance of lignocellulosic compounds in composting. In The Science of Composting, Part 1, eds. M. de Bertoldi, P. Sequi, B. Lemmes and T. Papi. pp. 531 \pm 541 . London, England: Chapman and Hall. ISBN 0751403830. Wong, P.T.W. and B

Zhang, J., Zeng, G., Chen, Y., Liang, J., Zhang, C., Huang, B., Sun, W., Chen, M., Yu, M., Huang, H. and Zhu, Y. (2014). Phanerochaete chrysosporium inoculation shapes the indigenous fungal communities during agricultural waste composting. Biodegradation; 25:669-680.

\section{How to cite this article:}

Ogunlade, M.O., O.S. Bello, S.O. Agbeniyi and Adeniyi, D.O. 2019. Microbiota Assay of Cocoa Pod Husk - Based Compost as Organic Fertilizer. Int.J.Curr.Microbiol.App.Sci. 8(02): 3182-3192. doi: https://doi.org/10.20546/ijcmas.2019.806.380 